\title{
Nocodazole Induced Suicidal Death of Human Erythrocytes
}

\author{
Elena Signoretto ${ }^{a, b}$ Sabina Honisch ${ }^{a}$ Marilena Briglia ${ }^{a, c}$ Caterina Faggio ${ }^{c}$ \\ Michela Castagna ${ }^{b}$ Florian Lang ${ }^{a}$ \\ aDepartment of Physiology, University of Tübingen, Tuebingen, Germany; ${ }^{b}$ Department of \\ Pharmacological and Biomolecular Sciences, Università degli Studi di Milano, Milano, Italy; \\ 'Department of Chemical, Biological, Pharmaceutical and Environmental Sciences-University \\ of Messina Viale Ferdinando Stagno d'Alcontres, S. Agata-Messina, Italy
}

\section{Key Words}

Phosphatidylserine $\cdot$ Cell volume $\bullet$ Eryptosis $\bullet$ Oxidative stress $\bullet$ Calcium

\begin{abstract}
Background: The microtubule assembly inhibitor nocodazole has been shown to trigger caspase-independent mitotic death and caspase dependent apoptosis. Similar to apoptosis of nucleated cells, erythrocytes may undergo eryptosis, the suicidal erythrocyte death characterized by cell shrinkage and cell membrane scrambling with phosphatidylserine translocation to the erythrocyte surface. Stimulators of eryptosis include increase of cytosolic $\mathrm{Ca}^{2+}$ activity $\left(\left[\mathrm{Ca}^{2+}\right]_{\mathrm{i}}\right)$, oxidative stress and ceramide. The present study explored, whether and how nocodazole induces eryptosis. Methods: Flow cytometry was employed to determine phosphatidylserine exposure at the cell surface from annexin-V-binding, cell volume from forward scatter, $\left[\mathrm{Ca}^{2+}\right]_{i}$ from Fluo3-fluorescence, the abundance of reactive oxygen species (ROS) from 2', 7'-dichlorodihydrofluorescein (DCF) diacetate dependent fluorescence as well as ceramide surface abundance utilizing specific antibodies. Tubulin abundance was quantified by TubulinTracker ${ }^{\mathrm{TM}}$ Green reagent and visualized by confocal microscopy. Results: A 48 hours exposure of human erythrocytes to nocodazole $(\geq 30 \mu \mathrm{g} / \mathrm{ml})$ significantly increased the percentage of annexin-V-binding cells without significantly modifying average forward scatter. Nocodazole significantly increased Fluo3-fluorescence, significantly increased DCF fluorescence and significantly increased ceramide surface abundance. The effect of nocodazole on annexin-V-binding was significantly blunted, but not abolished by removal of extracellular $\mathrm{Ca}^{2+}$ and was not modified in the presence of Caspase 3 inhibitor ZVAD ( 1 $\mu \mathrm{M})$. Nocodazole treatment reduced the content of total tubulin. Conclusions: Nocodazole triggers cell shrinkage and phospholipid scrambling of the erythrocyte cell membrane, an effect in part due to stimulation of $\mathrm{Ca}^{2+}$ entry, oxidative stress and ceramide.
\end{abstract}




\section{Cellular Physiology Cell Physiol Biochem 2016;38:379-392

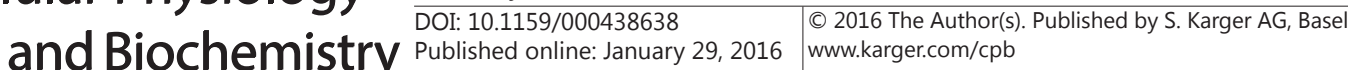 \\ Signoretto et al.: Nocodazole-Induced Eryptosis}

\section{Introduction}

Nocodazole interferes with microtubule assembly [1-14] thus interfering with mitosis due to formation of multipolar spindles $[15,16]$ and leading to cell cycle arrest in G2/M [8, 17-19]. Moreover, nocodazole causes cellular bulging and/or bending [20]. By interacting with microtubule function [21] nocodazole or related substances trigger caspaseindependent mitotic death [22] or caspase dependent apoptosis $[2,5,7,10,13,16,17,23$ 28]. The triggering of apoptosis involves downregulation of mTOR [29], inactivation of the antiapoptotic Bcl-2 [2, 4, 23, 29] and mitochondrial depolarization [23]. Nocodazole is thus effective against malignancy $[2,5,14,15,17,21]$. On the other hand, nocodazole counteracts TNF- $\alpha$-induced activation of the mitogen-activated protein kinase p38 [30].

Similar to apoptosis of nucleated cells, erythrocytes may enter eryptosis [31], the suicidal death of erythrocytes characterized by cell shrinkage [32] and cell membrane scrambling with phosphatidylserine translocation to the cell surface [31]. Triggers of eryptosis include increase of cytosolic $\mathrm{Ca}^{2+}$ activity $\left(\left[\mathrm{Ca}^{2+}\right]_{\mathrm{i}}\right)$, ceramide [33], oxidative stress [31], energy depletion [31] activated caspases [34, 35], stimulated activity of casein kinase $1 \alpha$, Janusactivated kinase JAK3, protein kinase C, and p38 kinase [31], as well as impaired activity of AMP activated kinase AMPK, cGMP-dependent protein kinase, PAK2 kinase, mitogen- and stress-activated kinase MSK1/2 and sorafenib/sunitinib sensitive kinases [31, 36].

The present study explored whether nocodazole induces eryptosis. To this end, human erythrocytes from healthy volunteers were treated with nocodazole and phosphatidylserine surface abundance, cell volume, $\left[\mathrm{Ca}^{2+}\right]_{i}$, reactive oxygen species (ROS) and ceramide abundance determined by flow cytometry.

\section{Materials and Methods}

Erythrocytes, solutions and chemicals

Fresh Li-Heparin-anticoagulated blood samples were kindly provided by the blood bank of the University of Tübingen. The study is approved by the ethics committee of the University of Tübingen (184/2003 V). The blood was centrifuged at $120 \mathrm{~g}$ for $20 \mathrm{~min}$ at $21^{\circ} \mathrm{C}$ and the platelets and leukocytes-containing supernatant was disposed. Erythrocytes were incubated in vitro at a hematocrit of $0.4 \%$ in Ringer solution containing (in $\mathrm{mM}$ ) $125 \mathrm{NaCl}, 5 \mathrm{KCl}, 1 \mathrm{MgSO}_{4}, 32 \mathrm{~N}$-2-hydroxyethylpiperazine-N-2-ethanesulfonic acid (HEPES; pH 7.4), 5 glucose, $1 \mathrm{CaCl}_{2}$, at $37^{\circ} \mathrm{C}$ for $48 \mathrm{~h}$. Where indicated, erythrocytes were exposed to nocodazole (Sigma Aldrich, Hamburg, Germany) at the indicated concentrations.

\section{Annexin-V-binding and forward scatter}

After incubation under the respective experimental condition, $100 \mu \mathrm{l}$ cell suspension was washed in Ringer solution containing $5 \mathrm{mM} \mathrm{CaCl}_{2}$ and then stained with Annexin-V-FITC (1:200 dilution; ImmunoTools, Friesoythe, Germany) in this solution at $37^{\circ} \mathrm{C}$ for $20 \mathrm{~min}$ under protection from light. The annexin-V abundance at the erythrocyte surface was subsequently determined on a FACS Calibur (BD, Heidelberg, Germany). A dot plot of forward scatter (FSC) vs. side scatter (SSC) was set to linear scale for both parameters. The threshold of forward scatter was set at the default value of " 52 ".

\section{Intracellular $\mathrm{Ca}^{2+}$}

After treatment, erythrocytes were washed in Ringer solution and then loaded with $5 \mu \mathrm{M}$ Fluo-3/AM (Biotium, Hayward, USA) in Ringer solution. The cells were incubated at $37^{\circ} \mathrm{C}$ for $30 \mathrm{~min}$ and washed once in Ringer solution. The Fluo-3/AM-loaded erythrocytes were resuspended in $200 \mu \mathrm{l}$ Ringer. Then, $\mathrm{Ca}^{2+}$ dependent fluorescence intensity was measured with an excitation wavelength of $488 \mathrm{~nm}$ and an emission wavelength of $530 \mathrm{~nm}$ on a FACS Calibur (BD, Heidelberg, Germany).

Measurement of hemolysis

For the determination of hemolysis, the samples were centrifuged $(10 \mathrm{~min}$ at $2000 \mathrm{rpm}$, room temperature) and the supernatants were collected. As a measure of hemolysis, the hemoglobin ( $\mathrm{Hb})$ 


\section{Cellular Physiology Cell Physiol Biochem 2016;38:379-392 \begin{tabular}{l|l|l}
\hline and BOI: 10.1159/000438638 & $\begin{array}{l}\text { C) 2016 The Author(s). Published by S. Karger AG, Basel } \\
\text { www.karger.com/cpb }\end{array}$
\end{tabular} \\ Signoretto et al.: Nocodazole-Induced Eryptosis}

concentration of the supernatant was determined photometrically at $405 \mathrm{~nm}$. The absorption of the supernatant of erythrocytes lysed in distilled water was defined as $100 \%$ hemolysis.

Reactive oxidant species (ROS)

Oxidative stress was determined utilizing 2',7'-dichlorodihydrofluorescein diacetate (DCFDA). After incubation, a $100 \mu \mathrm{l}$ suspension of erythrocytes was washed in Ringer solution and then stained with DCFDA (Sigma, Schnelldorf, Germany) in PBS containing DCFDA at a final concentration of $10 \mu \mathrm{M}$. Erythrocytes were incubated at $37^{\circ} \mathrm{C}$ for $30 \mathrm{~min}$ in the dark and then washed in PBS. The DCFDA-loaded erythrocytes were resuspended in $200 \mu \mathrm{l}$ Ringer solution, and ROS-dependent fluorescence intensity was measured at an excitation wavelength of $488 \mathrm{~nm}$ and an emission wavelength of $530 \mathrm{~nm}$ on a FACS Calibur (BD).

\section{Ceramide abundance}

For the determination of ceramide, a monoclonal antibody-based assay was used. After incubation, cells were stained for 1 hour at $37^{\circ} \mathrm{C}$ with $1 \mu \mathrm{g} / \mathrm{ml}$ anti ceramide antibody (clone MID 15B4, Alexis, Grünberg, Germany) in PBS containing $0.1 \%$ bovine serum albumin (BSA) at a dilution of 1:10. The samples were washed twice with PBS-BSA. Subsequently, the cells were stained for 30 minutes with polyclonal fluorescein isothiocyanate (FITC) conjugated goat anti-mouse IgG and IgM specific antibody (Pharmingen, Hamburg, Germany) diluted 1:50 in PBS-BSA. Unbound secondary antibody was removed by repeated washing with PBS-BSA. The samples were then analyzed by flow cytometric analysis with an excitation wavelength of 488 $\mathrm{nm}$ and an emission wavelength of $530 \mathrm{~nm}$.

\section{Tubulin staining}

For studying the effect of nocodazole on tubulin in human erythrocytes TubulinTracker ${ }^{\mathrm{TM}}$ Green reagent (Oregon Green $® 488$ Taxol; bis-acetate, Thermo Fisher Scientific, MA, USA) was used. Briefly, treated samples were stained with TubulinTracker $(250 \mathrm{nM})$ for $30 \mathrm{~min}$ in the dark at $37^{\circ} \mathrm{C}$. The erythrocytes were washed twice and finally resuspended in $200 \mu \mathrm{l}$ Ringer solution containing $5 \mathrm{mM} \mathrm{CaCl}_{2}$. For flow cytometry, TubulinTracker-dependent fluorescence of the samples was measured with an excitation wavelength of 488 $\mathrm{nm}$ and an emission wavelength of $530 \mathrm{~nm}$ on a FACS Calibur (BD). For confocal microscopy, $60 \mu \mathrm{l}$ of each sample were spread onto a glass slide and dried for 15 minutes at RT. The slides were covered with PROlong Gold antifade reagent (Invitrogen, Darmstadt Germany). Images were taken on a Zeiss LSM 5 EXCITER confocal laser-scanning microscope or with phase light (Carl Zeiss MicroImaging, Germany) with a water immersion Plan-Neofluar 63/1.3 NA DIC.

\section{Statistics}

Data are expressed as arithmetic means \pm SEM. As indicated in the figure legends, statistical analysis was made using ANOVA with Tukey's test as post-test and $t$ test as appropriate. $\mathrm{n}$ denotes the number of different erythrocyte specimens studied. Since different erythrocyte specimens used in distinct experiments are differently susceptible to triggers of eryptosis, the same erythrocyte specimens have been used for control and experimental conditions.

\section{Results}

The present study aimed to possibly disclose an effect of nocodazole on eryptosis, the suicidal erythrocyte death characterized by cell shrinkage and cell membrane scrambling with phosphatidylserine translocation to the cell surface. In order to identify phosphatidylserine exposing erythrocytes the erythrocytes were incubated with annexin-V which tightly binds to surface phosphatidylserine. Annexin- $V$ abundance was quantified by flow cytometry. The measurements were made following a 48 hours incubation in Ringer solution without or with nocodazole (15- $60 \mu \mathrm{g} / \mathrm{ml})$. As illustrated in Fig. 1, a 48 hours exposure to nocodazole increased the percentage of phosphatidylserine exposing erythrocytes, an effect reaching statistical significance at $30 \mu \mathrm{g} / \mathrm{ml}$ nocodazole.

In order to estimate erythrocyte volume, forward scatter was determined utilizing flow cytometry following a 48 hours incubation in Ringer solution without or with nocodazole 
A

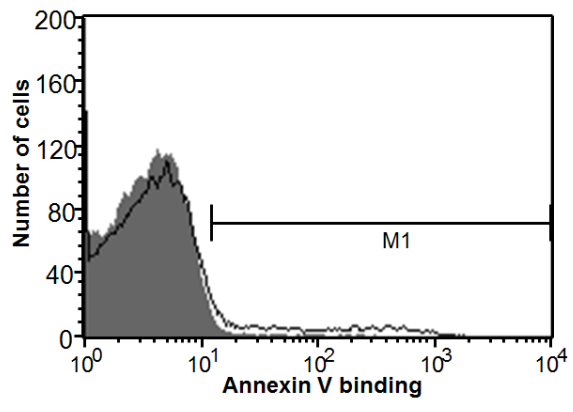

B

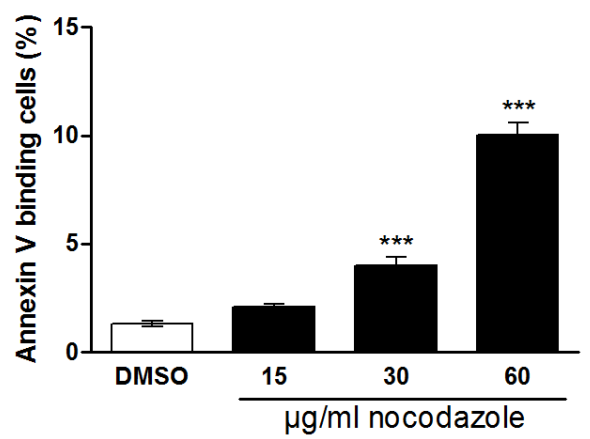

Fig. 1. Effect of nocodazole on phosphatidylserine exposure. A. Original histogram of annexin-V-binding of erythrocytes following exposure for 48 hours to Ringer solution with solvent DMSO (grey area) and with presence of $60 \mu \mathrm{g} / \mathrm{ml}$ nocodazole (black line). B. Arithmetic means \pm SEM $(\mathrm{n}=8)$ of the percentage of annexin-V-binding erythrocytes (black bars) following incubation for 48 hours to Ringer solution without or with presence of nocodazole $(15-60 \mu \mathrm{g} / \mathrm{ml}) .{ }^{* * *}(\mathrm{p}<0.001)$ indicates significant difference from the absence of nocodazole (ANOVA).

\section{A}

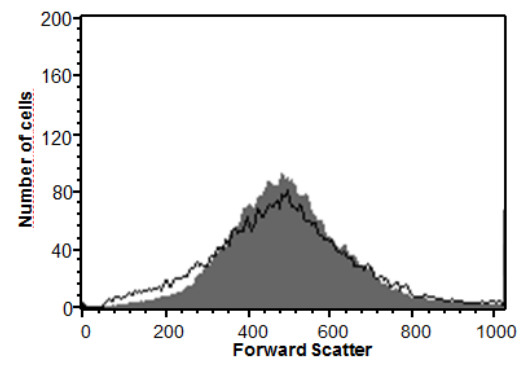

C

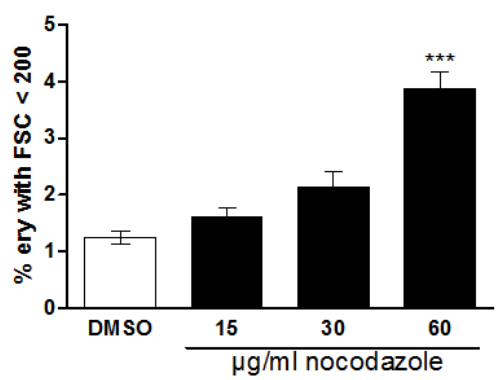

B

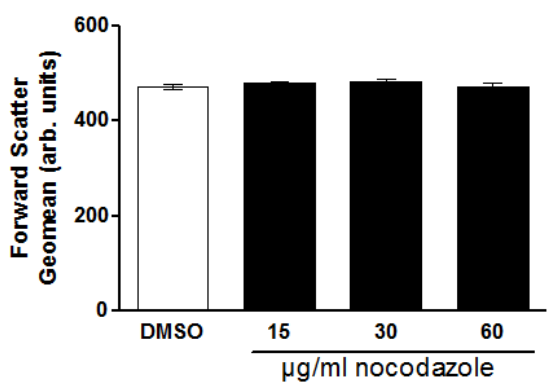

D

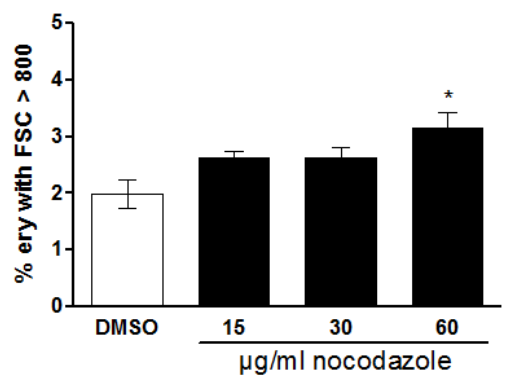

Fig. 2. Effect of nocodazole on erythrocyte forward scatter. A. Original histogram of forward scatter of erythrocytes following exposure for 48 hours to Ringer solution with solvent DMSO (grey area) and with presence of $60 \mu \mathrm{g} / \mathrm{ml}$ nocodazole (black line). B. Arithmetic means \pm SEM $(n=8)$ of the erythrocyte forward scatter (FSC) following incubation for 48 hours to Ringer solution without (white bar) or with (black bars) nocodazole $(15-60 \mu \mathrm{g} / \mathrm{ml})$. C. Arithmetic means \pm SEM $(\mathrm{n}=8)$ of the percentage erythrocytes with forward scatter (FSC) < 200 following incubation for 48 hours to Ringer solution without (white bar) or with (black bars) nocodazole $(15-60 \mu \mathrm{g} / \mathrm{ml})$. D. Arithmetic means \pm SEM $(\mathrm{n}=8)$ of the percentage erythrocytes with forward scatter (FSC) $>800$ following incubation for 48 hours to Ringer solution without (white bar) or with (black bars) nocodazole $(15-60 \mu \mathrm{g} / \mathrm{ml}) \cdot{ }^{*}(\mathrm{p}<0.05),{ }^{* * *}(\mathrm{p}<0.001)$ indicate significant difference from the absence of nocodazole (ANOVA). 

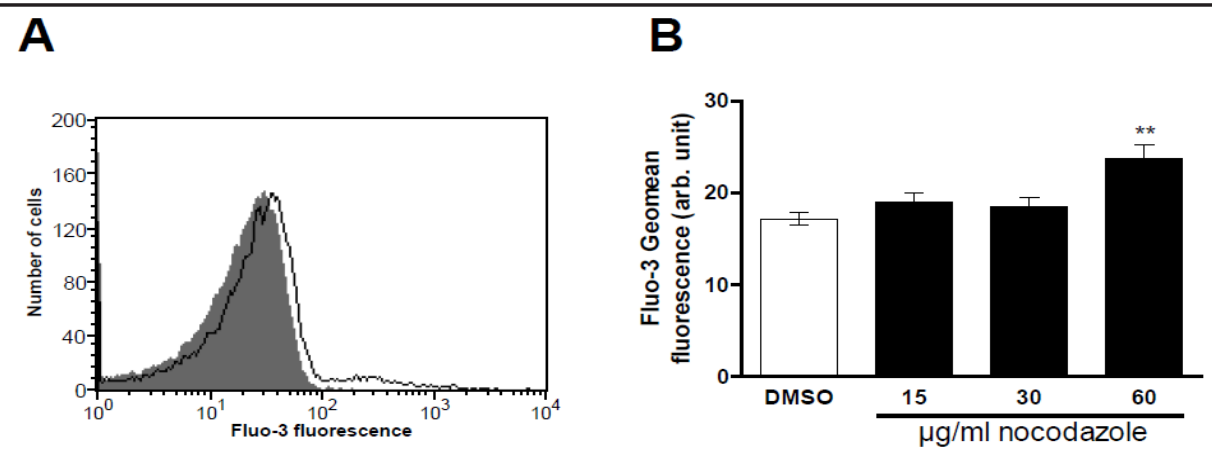

Fig. 3. Effect of nocodazole on erythrocyte $\mathrm{Ca}^{2+}$ activity. A. Original histogram of Fluo3-fluorescence in erythrocytes following exposure for 48 hours to Ringer solution with solvent DMSO (grey area) and with presence of $60 \mu \mathrm{g} / \mathrm{ml}$ nocodazole (black line). B. Arithmetic means \pm SEM $(\mathrm{n}=8)$ of the Fluo3-fluorescence (arbitrary units) in erythrocytes exposed for 48 hours to Ringer solution without (white bar) or with (black bars) nocodazole $(15-60 \mu \mathrm{g} / \mathrm{ml}) .{ }^{* *}(\mathrm{p}<0.01)$ indicate significant difference from the absence of nocodazole (ANOVA).

$(15-60 \mu \mathrm{g} / \mathrm{ml})$. As shown in Fig. 2, at none of the applied concentrations, nocodazole had a significant effect on average erythrocyte forward scatter. Close inspection of Fig. 2A reveals, however, that exposure of erythrocytes to nocodazole was followed by an increase of the percentage of both small (Fig. 2C) and large (Fig. 2D) erythrocytes, alterations reaching significance at nocodazole concentrations of $60 \mu \mathrm{g} / \mathrm{ml}$.

Hemolysis was estimated from the hemoglobin concentration in the supernatant which was determined by photometry. As a result, following a 48 hours incubation, the percentage of hemolytic erythrocytes was similar in the absence of nocodazole $(3.4 \pm 0.2 \% \mathrm{n}=12)$ and in the presence of $15 \mu \mathrm{g} / \mathrm{ml}(4.4 \pm 0.2 \% \mathrm{n}=12)$ or $30 \mu \mathrm{g} / \mathrm{ml}(4.7 \pm 0.2 \% \mathrm{n}=12)$ nocodazole. Exposure to $60 \mu \mathrm{g} / \mathrm{ml}$ nocodazole was, however, followed by a significant increase of hemolysis $(11.1 \pm 0.9 \% \mathrm{n}=12)$.

Cytosolic $\mathrm{Ca}^{2+}$ activity $\left(\left[\mathrm{Ca}^{2+}\right]_{\mathrm{i}}\right)$ was determined by Fluo3-fluorescence. As illustrated in Fig. 3, a 48 hours exposure to nocodazole increased the Fluo3-fluorescence, an effect reaching statistical significance at $60 \mu \mathrm{g} / \mathrm{ml}$ nocodazole. In order to test whether the stimulation of cell membrane scrambling by nocodazole requires the entry of extracellular $\mathrm{Ca}^{2+}$, erythrocytes were incubated for 48 hours in the absence or presence of $60 \mu \mathrm{g} / \mathrm{ml}$ nocodazole in the presence or nominal absence of extracellular $\mathrm{Ca}^{2+}$. As shown in Fig. 4, removal of extracellular $\mathrm{Ca}^{2+}$ significantly blunted the effect of nocodazole on annexin-V-binding. Nevertheless, even in the absence extracellular $\mathrm{Ca}^{2+}$ nocodazole significantly increased the percentage of annexinV-binding erythrocytes. Thus, nocodazole-induced cell membrane scrambling was in part but not fully due to entry of extracellular $\mathrm{Ca}^{2+}$. Neither in the presence nor in the absence of extracellular $\mathrm{Ca}^{2+}$ did nocodazole significantly modify average forward scatter.

To test whether a 48 hours incubation with nocodazole modified the effect of excessive $\left[\mathrm{Ca}^{2+}\right]_{\mathrm{i}}$ on cell membrane scrambling or forward scatter, erythrocytes were exposed for 60 min to $\mathrm{Ca}^{2+}$ ionophore ionomycin $(1 \mu \mathrm{M})$. As a result, ionomycin increased the percentage of annexin-V-binding erythrocytes to similarly high levels in erythrocytes incubated with nocodazole (from $4.8 \pm 0.3 \%$ to $35.8 \pm 1.6 \% \mathrm{n}=4$ ) and in erythrocytes incubated without nocodazole (from $1.6 \pm 0.2 \%$ to $38.7 \pm 1.8 \% \mathrm{n}=4$ ). Ionomycin decreased the forward scatter to similarly low levels in erythrocytes incubated with nocodazole (from $432 \pm 8.8 \%$ to 124 $\pm 1.9 \%, \mathrm{n}=4$ ) and in erythrocytes incubated without nocodazole (from $440 \pm 8.8 \%$ to $123 \pm$ $4.4 \%, \mathrm{n}=4$ ).

Additional experiments were performed to elucidate the effect of nocodazole on oxidative stress. Reactive oxygen species(ROS) wereestimatedutilizing $2^{\prime}, 7^{\prime}$-dichlorodihydrofluorescein (DCF) diacetate. As illustrated in Fig. 5, a 48 hours exposure to nocodazole increased the DCF fluorescence, an effect reaching statistical significance at $30 \mu \mathrm{g} / \mathrm{ml}$ nocodazole. 


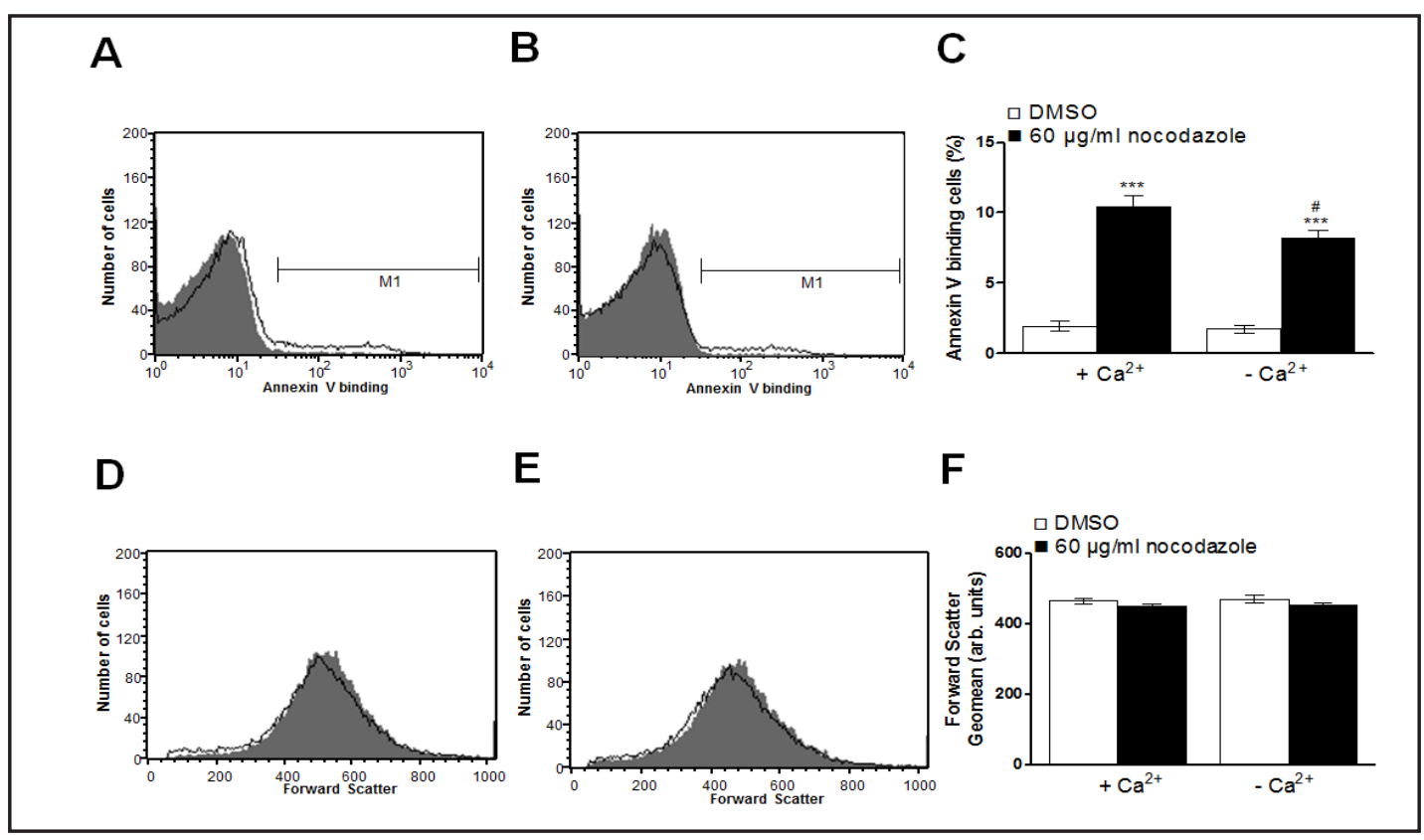

Fig. 4. $\mathrm{Ca}^{2+}$ sensitivity of nocodazole -induced phosphatidylserine exposure and erythrocyte shrinkage. A,B. Original histogram of annexin-V-binding of erythrocytes following exposure for 48 hours to Ringer solution with solvent DMSO (grey area) and with presence of $60 \mu \mathrm{g} / \mathrm{ml}$ nocodazole (black line) in the presence (A) and absence $(B)$ of extracellular $\mathrm{Ca}^{2+}$. C. Arithmetic means \pm SEM $(n=12)$ of the percentage of annexin-Vbinding erythrocytes after a 48 hours treatment with Ringer solution without (white bars) or with (black bars) nocodazole $(60 \mu \mathrm{g} / \mathrm{ml})$ in the presence (left bars, $\left.+\mathrm{Ca}^{2+}\right)$ and absence (right bars, $\left.-\mathrm{Ca}^{2+}\right)$ of $\mathrm{Ca}^{2+}$. D,E. Original histogram of erythrocyte forward scatter following exposure for 48 hours to Ringer solution with solvent DMSO (grey area) and with presence of $60 \mu \mathrm{g} / \mathrm{ml}$ nocodazole (black line) in the presence (D) and absence $(E)$ of extracellular $\mathrm{Ca}^{2+}$. F. Arithmetic means \pm SEM $(\mathrm{n}=12)$ of erythrocyte forward scatter after a 48 hours treatment with Ringer solution without (white bars) or with (black bars) nocodazole $(60 \mu \mathrm{g} / \mathrm{ml})$ in the presence (left bars, $\left.+\mathrm{Ca}^{2+}\right)$ and absence (right bars, $\left.-\mathrm{Ca}^{2+}\right)$ of $\mathrm{Ca}^{2+}$. ${ }^{* * *}(P<0.001)$ indicates significant difference from the absence of nocodazole, $\#(p<0.05)$ indicates significant difference from the presence of $\mathrm{Ca}^{2+}$ (ANOVA).

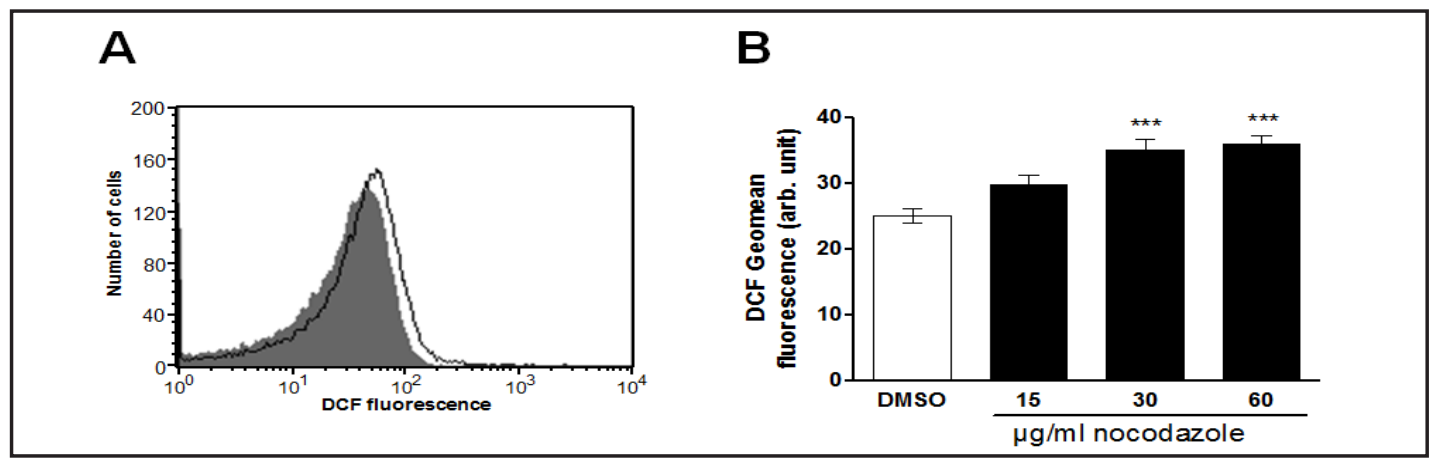

Fig. 5. Effect of nocodazole on erythrocyte ROS formation. A. Original histogram of DCF fluorescence in erythrocytes following exposure for 48 hours to Ringer solution with solvent DMSO (grey area) and with presence of $60 \mu \mathrm{g} / \mathrm{ml}$ nocodazole (black line). B. Arithmetic means \pm SEM $(\mathrm{n}=8)$ of the DCF fluorescence (arbitrary units) in erythrocytes exposed for 48 hours to Ringer solution without (white bar) or with (black bars) nocodazole $(15-60 \mu \mathrm{g} / \mathrm{ml}) .{ }^{* * *}(\mathrm{p}<0.001)$ indicates significant difference from the absence of nocodazole (ANOVA).

Eryptosis could further be stimulated by ceramide. Ceramide abundance at the erythrocyte surface was thus quantified with flow cytometry utilizing specific antibodies. As 
A

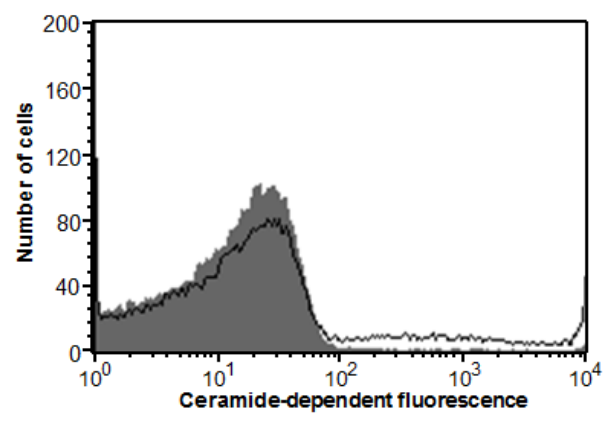

B

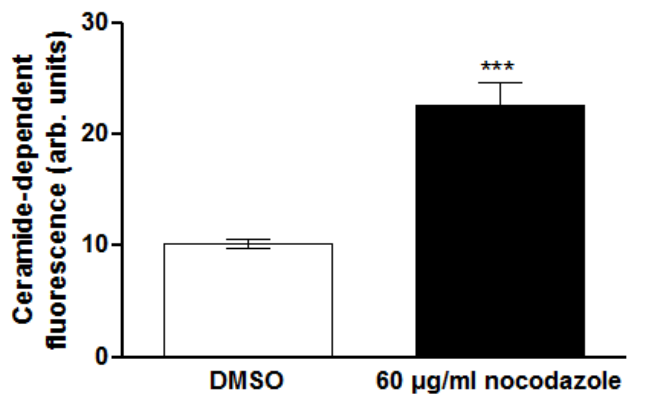

Fig. 6. Effect of nocodazole on ceramide abundance at the erythrocyte surface. A. Original histogram of ceramide abundance in erythrocytes following exposure for 48 hours to Ringer solution with solvent DMSO (grey area) and with presence of $60 \mu \mathrm{g} / \mathrm{ml}$ nocodazole (black line). B. Arithmetic means \pm SEM $(\mathrm{n}=9)$ of the ceramide abundance (arbitrary units) in erythrocytes exposed for 48 hours to Ringer solution without (white bar) or with (black bars) nocodazole $(60 \mu \mathrm{g} / \mathrm{ml}) .{ }^{* * *}(\mathrm{p}<0.001)$ indicates significant difference from the absence of nocodazole (Paired t test).

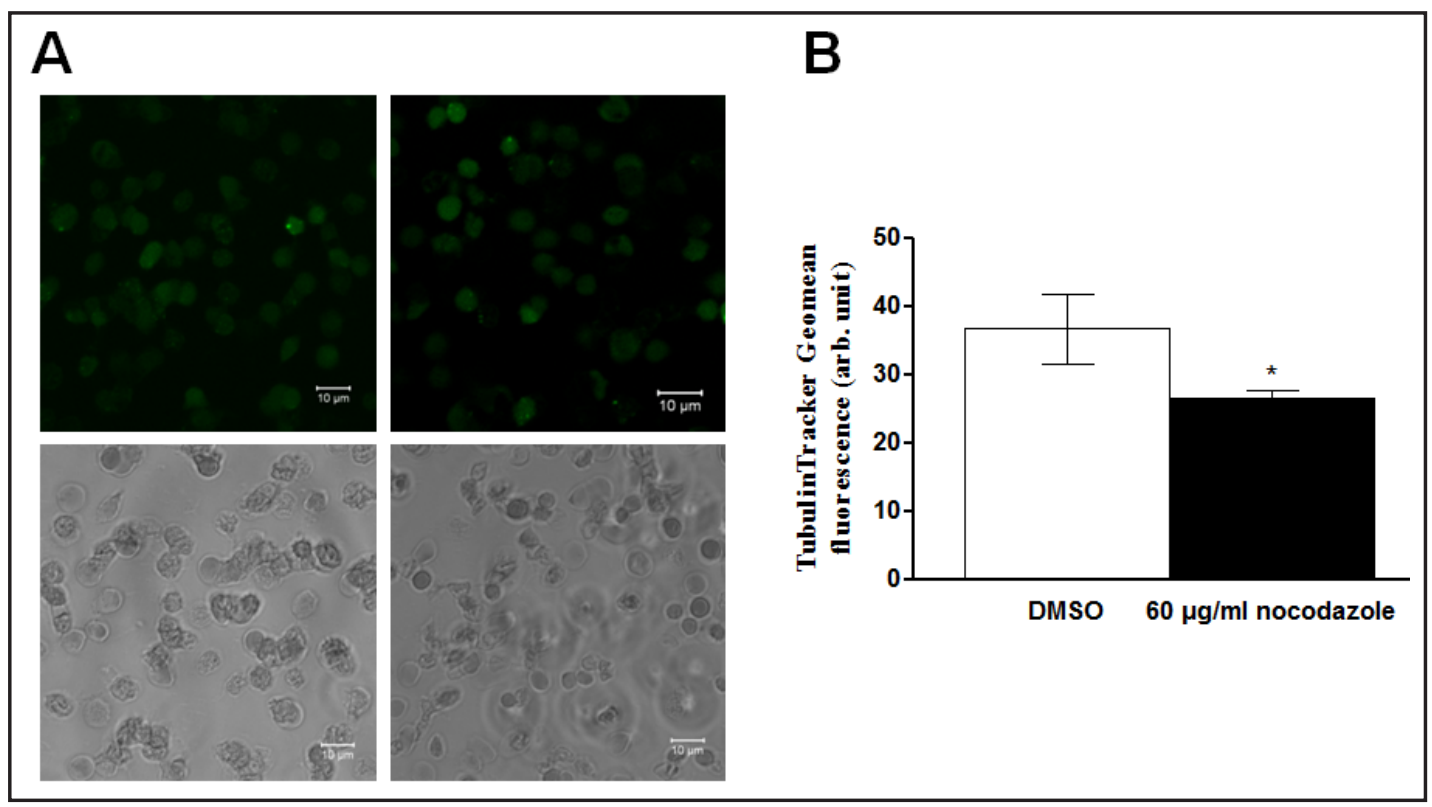

Fig. 7. Effect of nocodazole on tubulin abundance. A. Confocal images of tubulin abundance in erythrocytes following exposure for 48 hours to Ringer solution with solvent DMSO (left panel) and with presence of 60 $\mu \mathrm{g} / \mathrm{ml}$ nocodazole (right panel). B. Arithmetic means \pm SEM $(\mathrm{n}=4)$ of the TubulinTracker abundance (arbitrary units) in erythrocytes exposed for 48 hours to Ringer solution without (white bar) or with (black bars) nocodazole $(60 \mu \mathrm{g} / \mathrm{ml}) . *(\mathrm{p}<0.05)$ indicates significant difference from the absence of nocodazole (Paired t test).

illustrated in Fig. 6, a 48 hours exposure to nocodazole $(60 \mu \mathrm{g} / \mathrm{ml})$ significantly increased the ceramide abundance.

To investigate the effect of nocodazole on tubulin in erythrocytes, TubulinTracker reagent was utilized in both flow cytometry and confocal microscopy. As illustrated in Fig. $7,48 \mathrm{~h}$ treatment of erythrocytes with nocodazole $(60 \mu \mathrm{g} / \mathrm{ml})$ significantly reduced the TubulinTracker-dependent fluorescence.

To explore whether the stimulation of cell membrane scrambling by nocodazole required caspase activity, erythrocytes were exposed for $48 \mathrm{~h}$ to $60 \mu \mathrm{g} / \mathrm{ml}$ nocodazole either

\section{KARGER}


Fig. 8. Insensitivity of nocodazole induced phosphatidylserine exposure to caspase inhibitor zVAD. Arithmetic means \pm SEM $(n=9)$ of the percentage of annexin-V-binding erythrocytes following incubation for 48 hours to Ringer solution without (white bars) or with (black bars) nocodazole $(60 \mu \mathrm{g} / \mathrm{ml})$ treatment in the absence (-zVAD) or presence (+zVAD) of the pancaspase inhibitor zVAD $(1 \mu \mathrm{M})$. $* * *(p<0.001)$ indicates significant difference from the absence of nocodazole (ANOVA).

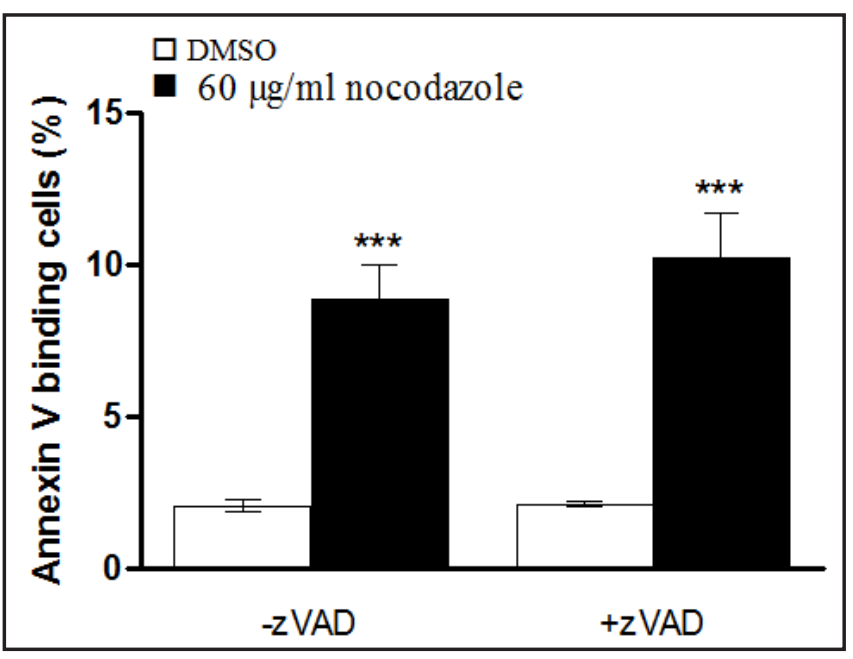

in the absence or presence of the pancaspase inhibitor zVAD $(1 \mu \mathrm{M})$. As illustrated in Fig. 8, zVAD did not significantly modify the effect of nocodazole on annexin-V-binding.

\section{Discussion}

The present observations demonstrate that nocodazole triggers cell membrane scrambling, the key event of suicidal erythrocyte death or eryptosis. The concentrations required for the toxic effect are higher than those required for disassembly of microtubules [13] but are similar to those previously employed to trigger cell cycle arrest [37].

The sensitivity to nocodazole may be particularly high in clinical conditions associated with enhanced eryptosis, such as dehydration [38], hyperphosphatemia [39] chronic kidney disease (CKD) [40-43], hemolytic-uremic syndrome [44], diabetes [45], hepatic failure [46], cardiac failure [47], malignancy [48], sepsis [49], fever [31, 50], sickle-cell disease [31], betathalassemia [31], Hb-C and G6PD-deficiency [31], Wilsons disease [51] as well as advanced age [52]. Moreover, the effect of nocodazole may be compounded by other eryptosis stimulating xenobiotics $[38,39,41,48,53-106]$.

The stimulation by nocodazole of cell membrane scrambling was in part due to increase of cytosolic $\mathrm{Ca}^{2+}$ activity $\left(\left[\mathrm{Ca}^{2+}\right]_{\mathrm{i}}\right)$ and was thus significantly blunted by removal of extracellular $\mathrm{Ca}^{2+}$. However, even in the absence of extracellular $\mathrm{Ca}^{2+}$ nocodazole treatment was followed by stimulation of cell membrane scrambling, pointing to additional mechanisms in the stimulation of eryptosis by nocodazole. Those mechanisms presumably include oxidative stress and ceramide.

Nocodazole did not significantly modify the average forward scatter but increased the percentage of both, shrunken and swollen erythrocytes. The cell shrinkage could be explained at least partially by increase of $\left[\mathrm{Ca}^{2+}\right]_{\mathrm{i}}$ with subsequent activation of $\mathrm{Ca}^{2+}$ sensitive $\mathrm{K}^{+}$channels, $\mathrm{K}^{+}$exit, cell membrane hyperpolarization, $\mathrm{Cl}^{-}$exit and thus cellular loss of $\mathrm{KCl}$ with water [32]. The mechanism driving nocodazole induced erythrocyte swelling remains elusive. A candidate mechanism could be impairment of $\mathrm{Na}^{+} / \mathrm{K}^{+}$ATPase with subsequent cellular accumulation of $\mathrm{Na}^{+}$with $\mathrm{Cl}$. Whatever mechanism is involved in nocodazole induced cell swelling, it leads to swelling of only a small subset of erythrocytes.

We observed a moderate decrease of tubulin abundance following nocodazole treatment. Whether this effect contributes to the stimulation of eryptosis, remains uncertain. In blood platelets $\mathrm{Ca}^{2+}$ induced apoptosis was seemingly insensitive to cytoskeletal rearrangement [107].

The nocodazole induced eryptosis was insensitive to the pancaspase inhibitor zVAD. Accordingly, the stimulation of cell membrane scrambling by nocodazole does apparently 
not require caspases. Suicidal death of nucleated cells may similarly be independent from caspase activation [108-110]. Suicidal cell death may involve activation of other enzymes. Eryptosis, for instance, may involve activation of calpain [31].

Stimulation of eryptosis may lead to anemia due to rapid clearance of eryptosic erythrocytes from circulating blood [31]. Eryptosis further leads to adherence of phosphatdylserine exposing erythrocytes to the vascular wall [111], to stimulation of blood clotting and to triggering of thrombosis [112-114]. Accordingly, enhanced eryptosis may lead to impairment of microcirculation [33, 112, 115-118].

In conclusion, nocodazole triggers eryptosis with cell membrane scrambling, an effect paralleled by and in part due to increase of cytosolic $\mathrm{Ca}^{2+}$ activity, oxidative stress and ceramide.

\section{Acknowledgements}

The authors acknowledge the meticulous preparation of the manuscript by Tanja Loch. The study was supported by the Deutsche Forschungsgemeinschaft and Open Access Publishing Fund of Tuebingen University.

\section{Disclosure Statement}

The authors of this manuscript state that they do not have any conflict of interests and nothing to disclose.

\section{References}

1 Bereiter-Hahn J, Voth M, Mai S, Jendrach M: Structural implications of mitochondrial dynamics. Biotechnol J 2008;3:765-780.

2 Beswick RW, Ambrose HE, Wagner SD: Nocodazole, a microtubule de-polymerising agent, induces apoptosis of chronic lymphocytic leukaemia cells associated with changes in Bcl-2 phosphorylation and expression. Leuk Res 2006;30:427-436.

3 Calaghan SC, Le Guennec JY, White E: Cytoskeletal modulation of electrical and mechanical activity in cardiac myocytes. Prog Biophys Mol Biol 2004;84:29-59.

4 Choi HJ, Zhu BT: Role of cyclin B1/Cdc2 in mediating Bcl-XL phosphorylation and apoptotic cell death following nocodazole-induced mitotic arrest. Mol Carcinog 2014;53:125-137.

5 Frezzato F, Trimarco V, Martini V, Gattazzo C, Ave E, Visentin A, Cabrelle A, Olivieri V, Zambello R, Facco M, Zonta F, Cristiani A, Brunati AM, Moro S, Semenzato G, Trentin L: Leukaemic cells from chronic lymphocytic leukaemia patients undergo apoptosis following microtubule depolymerization and Lyn inhibition by nocodazole. Br J Haematol 2014;165:659-672.

6 Gozes I: Microtubules (tau) as an emerging therapeutic target: NAP (davunetide). Curr Pharm Des 2011;17:3413-3417.

7 Ikegami R, Zhang J, Rivera-Bennetts AK, Yager TD: Activation of the metaphase checkpoint and an apoptosis programme in the early zebrafish embryo, by treatment with the spindle-destabilising agent nocodazole. Zygote 1997;5:329-350.

8 Kallas A, Pook M, Maimets M, Zimmermann K, Maimets T: Nocodazole treatment decreases expression of pluripotency markers Nanog and Oct4 in human embryonic stem cells. PLoS One 2011;6:e19114.

9 Kirsch-Volders M, Vanhauwaert A, Eichenlaub-Ritter U, Decordier I: Indirect mechanisms of genotoxicity. Toxicol Lett 2003;140-141:63-74.

10 Kook S, Shim SR, Kim JI, Ahnn JH, Jung YK, Paik SG, Song WK: Degradation of focal adhesion proteins during nocodazole-induced apoptosis in rat-1 cells. Cell Biochem Funct 2000;18:1-7.

11 Modriansky M, Dvorak Z: Microtubule disruptors and their interaction with biotransformation enzymes. Biomed Pap Med Fac Univ Palacky Olomouc Czech Repub 2005;149:213-215.

12 Rieder CL, Maiato H: Stuck in division or passing through: what happens when cells cannot satisfy the spindle assembly checkpoint. Dev Cell 2004;7:637-651. 


\section{Cellular Physiology Cell Physiol Biochem 2016;38:379-392

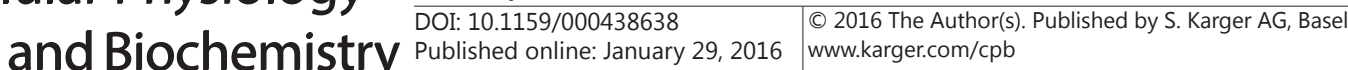 \\ Signoretto et al.: Nocodazole-Induced Eryptosis}

13 Verdoodt B, Decordier I, Geleyns K, Cunha M, Cundari E, Kirsch-Volders M: Induction of polyploidy and apoptosis after exposure to high concentrations of the spindle poison nocodazole. Mutagenesis 1999;14:513-520.

14 Zacharaki P, Stephanou G, Demopoulos NA: Comparison of the aneugenic properties of nocodazole, paclitaxel and griseofulvin in vitro. Centrosome defects and alterations in protein expression profiles. J Appl Toxicol 2013;33:869-879.

15 Bhakta-Guha D, Saeed ME, Greten HJ, Efferth T: Dis-organizing centrosomal clusters: specific cancer therapy for a generic spread? Curr Med Chem 2015;22:685-694.

16 Decordier I, Cundari E, Kirsch-Volders M: Survival of aneuploid, micronucleated and/or polyploid cells: crosstalk between ploidy control and apoptosis. Mutat Res 2008;651:30-39.

17 Ho YS, Duh JS, Jeng JH, Wang YJ, Liang YC, Lin CH, Tseng CJ, Yu CF, Chen RJ, Lin JK: Griseofulvin potentiates antitumorigenesis effects of nocodazole through induction of apoptosis and G2/M cell cycle arrest in human colorectal cancer cells. Int J Cancer 2001;91:393-401.

18 Hsu SL, Yu CT, Yin SC, Tang MJ, Tien AC, Wu YM, Huang CY: Caspase 3, periodically expressed and activated at G2/M transition, is required for nocodazole-induced mitotic checkpoint. Apoptosis 2006;11:765-771.

19 Scott RE, Gao S: P2P-R deficiency modifies nocodazole-induced mitotic arrest and UV-induced apoptosis. Anticancer Res 2002;22:3837-3842.

20 Katsaros C, Karyophyllis D, Galatis B: Cytoskeleton and morphogenesis in brown algae. Ann Bot 2006;97:679-693.

21 Agnese V, Bazan V, Fiorentino FP, Fanale D, Badalamenti G, Colucci G, Adamo V, Santini D, Russo A: The role of Aurora-A inhibitors in cancer therapy. Ann Oncol 2007;18 Suppl 6:vi47-52.

22 Kitagawa K, Niikura Y: Caspase-independent mitotic death (CIMD). Cell Cycle 2008;7:1001-1005.

23 Han CR, Jun do Y, Lee JY, Kim YH: Prometaphase arrest-dependent phosphorylation of Bcl-2 and Bim reduces the association of Bcl-2 with Bak or Bim, provoking Bak activation and mitochondrial apoptosis in nocodazole-treated Jurkat T cells. Apoptosis 2014;19:224-240.

24 Landsverk KS, Lyng H, Stokke T: The response of malignant B lymphocytes to ionizing radiation: cell cycle arrest, apoptosis and protection against the cytotoxic effects of the mitotic inhibitor nocodazole. Radiat Res 2004;162:405-415.

25 Li P, Zhou L, Dai Z, Jin X, Liu X, Matsumoto Y, Furusawa Y, Li Q: High LET radiation enhances nocodazole Induced cell death in HeLa cells through mitotic catastrophe and apoptosis. J Radiat Res 2011;52:481-489.

26 Song H, Kim SI, Ko MS, Kim HJ, Heo JC, Lee HJ, Lee HS, Han IS, Kwack K, Park JW: Overexpression of DRG2 increases G2/M phase cells and decreases sensitivity to nocodazole-induced apoptosis. J Biochem 2004;135:331-335.

27 Wang YJ, Jeng JH, Chen RJ, Tseng H, Chen LC, Liang YC, Lin CH, Chen CH, Chu JS, Ho WL, Ho YS: Ketoconazole potentiates the antitumor effects of nocodazole: In vivo therapy for human tumor xenografts in nude mice. Mol Carcinog 2002;34:199-210.

28 Zhang H, Shi X, Zhang QJ, Hampong M, Paddon H, Wahyuningsih D, Pelech S: Nocodazole-induced p53dependent c-Jun N-terminal kinase activation reduces apoptosis in human colon carcinoma HCT116 cells. J Biol Chem 2002;277:43648-43658.

29 Asnaghi L, Bruno P, Priulla M, Nicolin A: mTOR: a protein kinase switching between life and death. Pharmacol Res 2004;50:545-549.

30 Guo X, Zhang X, Li Y, Guo Y, Wang J, Li Y, Shen B, Sun D, Zhang J: Nocodazole increases the ERK activity to enhance MKP-1expression which inhibits p38 activation induced by TNF-alpha. Mol Cell Biochem 2012;364:373-380.

31 Lang E, Qadri SM, Lang F: Killing me softly - suicidal erythrocyte death. Int J Biochem Cell Biol 2012;44:1236-1243.

32 Lang PA, Kaiser S, Myssina S, Wieder T, Lang F, Huber SM: Role of Ca2+-activated K+ channels in human erythrocyte apoptosis. Am J Physiol Cell Physiol 2003;285:C1553-C1560.

33 Abed M, Towhid ST, Mia S, Pakladok T, Alesutan I, Borst O, Gawaz M, Gulbins E, Lang F: Sphingomyelinaseinduced adhesion of eryptotic erythrocytes to endothelial cells. Am J Physiol Cell Physiol 2012;303:C991999.

34 Lau IP, Chen H, Wang J, Ong HC, Leung KC, Ho HP, Kong SK: In vitro effect of CTAB- and PEG-coated gold nanorods on the induction of eryptosis/erythroptosis in human erythrocytes. Nanotoxicology 2012;6:847856. 


\section{Cellular Physiology Cell Physiol Biochem 2016;38:379-392

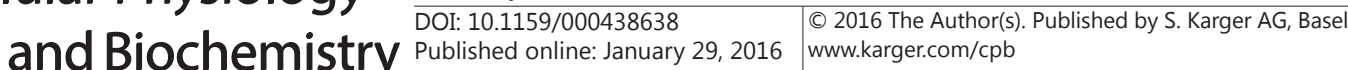 \\ Signoretto et al.: Nocodazole-Induced Eryptosis}

35 Maellaro E, Leoncini S, Moretti D, Del Bello B, Tanganelli I, De Felice C, Ciccoli L: Erythrocyte caspase-3 activation and oxidative imbalance in erythrocytes and in plasma of type 2 diabetic patients. Acta Diabetol 2013;50:489-495.

36 Lang E, Bissinger R, Fajol A, Salker MS, Singh Y, Zelenak C, Ghashghaeinia M, Gu S, Jilani K, Lupescu A, Reyskens KM, Ackermann TF, Foller M, Schleicher E, Sheffield WP, Arthur JS, Lang F, Qadri SM: Accelerated apoptotic death and in vivo turnover of erythrocytes in mice lacking functional mitogen- and stressactivated kinase MSK1/2. Sci Rep 2015;5:17316.

37 Avantaggiati ML, Ogryzko V, Gardner K, Giordano A, Levine AS, Kelly K: Recruitment of p300/CBP in p53dependent signal pathways. Cell 1997;89:1175-1184.

38 Abed M, Feger M, Alzoubi K, Pakladok T, Frauenfeld L, Geiger C, Towhid ST, Lang F: Sensitization of erythrocytes to suicidal erythrocyte death following water deprivation. Kidney Blood Press Res 2013;37:567-578.

39 Voelkl J, Alzoubi K, Mamar AK, Ahmed MS, Abed M, Lang F: Stimulation of suicidal erythrocyte death by increased extracellular phosphate concentrations. Kidney Blood Press Res 2013;38:42-51.

40 Abed M, Artunc F, Alzoubi K, Honisch S, Baumann D, Foller M, Lang F: Suicidal erythrocyte death in endstage renal disease. J Mol Med (Berl) 2014;92:871-879.

41 Ahmed MS, Langer H, Abed M, Voelkl J, Lang F: The uremic toxin acrolein promotes suicidal erythrocyte death. Kidney Blood Press Res 2013;37:158-167.

42 Polak-Jonkisz D, Purzyc L: Ca(2+) influx versus efflux during eryptosis in uremic erythrocytes. Blood Purif 2012;34:209-210; author reply 210.

43 Calderon-Salinas JV, Munoz-Reyes EG, Guerrero-Romero JF, Rodriguez-Moran M, Bracho-Riquelme RL, Carrera-Gracia MA, Quintanar-Escorza MA: Eryptosis and oxidative damage in type 2 diabetic mellitus patients with chronic kidney disease. Mol Cell Biochem 2011;357:171-179.

44 Lang PA, Beringer O, Nicolay JP, Amon O, Kempe DS, Hermle T, Attanasio P, Akel A, Schafer R, Friedrich B, Risler T, Baur M, Olbricht CJ, Zimmerhackl LB, Zipfel PF, Wieder T, Lang F: Suicidal death of erythrocytes in recurrent hemolytic uremic syndrome. J Mol Med (Berl) 2006;84:378-388.

45 Nicolay JP, Schneider J, Niemoeller OM, Artunc F, Portero-Otin M, Haik G, Jr., Thornalley PJ, Schleicher E, Wieder T, Lang F: Stimulation of suicidal erythrocyte death by methylglyoxal. Cell Physiol Biochem 2006;18:223-232.

46 Lang E, Gatidis S, Freise NF, Bock H, Kubitz R, Lauermann C, Orth HM, Klindt C, Schuier M, Keitel V, Reich M, Liu G, Schmidt S, Xu HC, Qadri SM, Herebian D, Pandyra AA, Mayatepek E, Gulbins E, Lang F, Haussinger D, Lang KS, Foller M, Lang PA: Conjugated bilirubin triggers anemia by inducing erythrocyte death. Hepatology 2015;61:275-284.

47 Attanasio P, Bissinger R, Haverkamp W, Pieske B, Wutzler A, Lang F: Enhanced suicidal erythrocyte death in acute cardiac failure. Eur J Clin Invest 2015;10.1111/eci.12555

48 Qadri SM, Mahmud H, Lang E, Gu S, Bobbala D, Zelenak C, Jilani K, Siegfried A, Foller M, Lang F: Enhanced suicidal erythrocyte death in mice carrying a loss-of-function mutation of the adenomatous polyposis coli gene. J Cell Mol Med 2012;16:1085-1093.

49 Kempe DS, Akel A, Lang PA, Hermle T, Biswas R, Muresanu J, Friedrich B, Dreischer P, Wolz C, Schumacher U, Peschel A, Gotz F, Doring G, Wieder T, Gulbins E, Lang F: Suicidal erythrocyte death in sepsis. J Mol Med (Berl) 2007;85:273-281.

50 Crisp RL, Vota DM, Donato H, Garcia E, Rapetti MC, Maltaneri RE, Vittori DC, Nesse AB: Eryptosis is induced by hyperthermia in hereditary spherocytosis red blood cells. Clin Chem Lab Med 2015;10.1515/cclm2015-0618

51 Lang PA, Schenck M, Nicolay JP, Becker JU, Kempe DS, Lupescu A, Koka S, Eisele K, Klarl BA, Rubben H, Schmid KW, Mann K, Hildenbrand S, Hefter H, Huber SM, Wieder T, Erhardt A, Haussinger D, Gulbins E, Lang F: Liver cell death and anemia in Wilson disease involve acid sphingomyelinase and ceramide. Nat Med 2007;13:164-170.

52 Lupescu A, Bissinger R, Goebel T, Salker MS, Alzoubi K, Liu G, Chirigiu L, Mack AF, Qadri SM, Lang F: Enhanced suicidal erythrocyte death contributing to anemia in the elderly. Cell Physiol Biochem 2015;36:773-783.

53 Alzoubi K, Honisch S, Abed M, Lang F: Triggering of Suicidal Erythrocyte Death by Penta-O-galloyl-beta-dglucose. Toxins (Basel) 2014;6:54-65. 


\section{Cellular Physiology Cell Physiol Biochem 2016;38:379-392 \begin{tabular}{l|l|l|l}
\hline DOI: 10.1159/000438638 20,2016 & $\begin{array}{l}\text { (c) 2016 The Author(s). Published by S. Karger AG, Basel } \\
\text { www.karger.com/cpb }\end{array}$
\end{tabular} \\ Signoretto et al.: Nocodazole-Induced Eryptosis}

54 Arnold M, Lang E, Modicano P, Bissinger R, Faggio C, Abed M, Lang F: Effect of nitazoxanide on erythrocytes. Basic Clin Pharmacol Toxicol 2014;114:421-426.

55 Oswald G, Alzoubi K, Abed M, Lang F: Stimulation of suicidal erythrocyte death by ribavirin. Basic Clin Pharmacol Toxicol 2014;114:311-317.

56 Alzoubi K, Calabròa S, Bissinger R, Abed M, Faggio C, Lang F: Stimulation of Suicidal Erythrocyte Death by Artesunate. Cell Physiol Biochem 2014;34:2232-2244.

57 Arnold M, Bissinger R, Lang F: Mitoxantrone-induced suicidal erythrocyte death. Cell Physiol Biochem 2014;34:1756-1767.

58 Bissinger R, Fischer S, Jilani K, Lang F: Stimulation of Erythrocyte Death by Phloretin. Cell Physiol Biochem 2014;34:2256-2265.

59 Jacobi J, Lang E, Bissinger R, Frauenfeld L, Modicano P, Faggio C, Abed M, Lang F: Stimulation of erythrocyte cell membrane scrambling by mitotane. Cell Physiol Biochem 2014;33:1516-1526.

60 Jilani K, Qadri SM, Lang F: Geldanamycin-induced phosphatidylserine translocation in the erythrocyte membrane. Cell Physiol Biochem 2013;32:1600-1609.

61 Lupescu A, Bissinger R, Herrmann T, Oswald G, Jilani K, Lang F: Induction of suicidal erythrocyte death by novobiocin. Cell Physiol Biochem 2014;33:670-680.

62 Malik A, Bissinger R, Calabro S, Faggio C, Jilani K, Lang F: Aristolochic Acid Induced Suicidal Erythrocyte Death. Kidney Blood Press Res 2014;39:408-419.

63 Tesoriere L, Attanzio A, Allegra M, Cilla A, Gentile C, Livrea MA: Oxysterol mixture in hypercholesterolemiarelevant proportion causes oxidative stress-dependent eryptosis. Cell Physiol Biochem 2014;34:10751089.

64 Zhang R, Xiang Y, Ran Q, Deng X, Xiao Y, Xiang L, Li Z: Involvement of calcium, reactive oxygen species, and ATP in hexavalent chromium-induced damage in red blood cells. Cell Physiol Biochem 2014;34:1780-1791.

65 Aljanadi O, Alzoubi K, Bissinger R, Lang F: Stimulation of Suicidal Erythrocyte Death by Naphthazarin. Basic Clin Pharmacol Toxicol 2015;10.1111/bcpt.12420

66 Alzoubi K, Egler J, Abed M, Lang F: Enhanced Eryptosis Following Auranofin Exposure. Cell Physiol Biochem 2015;37:1018-1028.

67 Alzoubi K, Egler J, Briglia M, Fazio A, Faggio C, Lang F: Induction of Suicidal Erythrocyte Death by Cantharidin. Toxins (Basel) 2015;7:2822-2834.

68 Awasthi S, Gayathiri SK, Ramya R, Duraichelvan R, Dhason A, Saraswathi NT: Advanced Glycation-Modified Human Serum Albumin Evokes Alterations in Membrane and Eryptosis in Erythrocytes. Appl Biochem Biotechnol 2015;177:1013-1024.

69 Bissinger R, Barking S, Alzoubi K, Liu G, Liu G, Lang F: Stimulation of Suicidal Erythrocyte Death by the Antimalarial Drug Mefloquine. Cell Physiol Biochem 2015;36:1395-1405.

70 Bissinger R, Bouguerra G, Stockinger K, Abbes S, Lang F: Triggering of Suicidal Erythrocyte Death by Topotecan. Cell Physiol Biochem 2015;37:1607-1618.

71 Bissinger R, Malik A, Bouguerra G, Zhou Y, Singh Y, Abbes S, Lang F: Triggering of Suicidal Erythrocyte Death by the Antibiotic Ionophore Nigericin. Basic Clin Pharmacol Toxicol 2015;10.1111/bcpt.12503

72 Bissinger R, Waibel S, Bouguerra G, Al Mamun Bhuyan A, Abbes S, Lang F: Enhanced Eryptosis Following Exposure to Lopinavir. Cell Physiol Biochem 2015;37:2486-2495.

73 Bissinger R, Waibel S, Lang F: Induction of suicidal erythrocyte death by nelfinavir. Toxins (Basel) 2015;7:1616-1628.

74 Bouguerra G, Aljanadi O, Bissinger R, Abbes S, Lang F: Embelin-Induced Phosphatidylserine Translocation in the Erythrocyte Cell Membrane. Cell Physiol Biochem 2015;37:1629-1640.

75 Bouguerra G, Bissinger R, Abbes S, Lang F: Stimulation of Eryptosis by Narasin. Cell Physiol Biochem 2015;37:1807-1816.

76 Bouguerra G, Bissinger R, Abbes S, Lang F: Zopolrestat Induced Suicidal Death of Human Erythrocytes. Cell Physiol Biochem 2015;37:1537-1546.

77 Briglia M, Calabro S, Signoretto E, Alzoubi K, Laufer S, Faggio C, Lang F: Fucoxanthin Induced Suicidal Death of Human Erythrocytes. Cell Physiol Biochem 2015;37:2464-2475.

78 Briglia M, Fazio A, Faggio C, Lang F: Triggering of Suicidal Erythrocyte Death by Zosuquidar. Cell Physiol Biochem 2015;37:2355-2365.

79 Briglia M, Fazio A, Faggio C, Laufer S, Alzoubi K, Lang F: Triggering of Suicidal Erythrocyte Death by Ruxolitinib. Cell Physiol Biochem 2015;37:768-778. 


\section{Cellular Physiology Cell Physiol Biochem 2016;38:379-392 \begin{tabular}{l|l|l} 
and BOI: 10.1159/000438638 20,2016 & $\begin{array}{l}\text { () 2016 The Author(s). Published by S. Karger AG, Basel } \\
\text { www.karger.com/cpb }\end{array}$
\end{tabular} \\ Signoretto et al.: Nocodazole-Induced Eryptosis}

80 Briglia M, Fazio A, Signoretto E, Faggio C, Lang F: Edelfosine Induced Suicidal Death of Human Erythrocytes. Cell Physiol Biochem 2015;37:2221-2230.

81 Calabro S, Alzoubi K, Bissinger R, Faggio C, Lang F: Stimulation of suicidal erythrocyte death by ellipticine. Basic Clin Pharmacol Toxicol 2015;116:485-492.

82 Calabro S, Alzoubi K, Faggio C, Laufer S, Lang F: Triggering of Suicidal Erythrocyte Death Following Boswellic Acid Exposure. Cell Physiol Biochem 2015;37:131-142.

83 Cheung AK, Yang AK, Ngai BH, Yu SS, Gao M, Lau PM, Kong SK: Quantitative detection of eryptosis in human erythrocytes using tunable resistive pulse sensing and annexin-V-beads. Analyst 2015;140:1337-1348.

84 Egler J, Lang F: Licochalcone A Induced Suicidal Death of Human Erythrocytes. Cell Physiol Biochem 2015;37:2060-2070.

85 Faggio C, Alzoubi K, Calabro S, Lang F: Stimulation of suicidal erythrocyte death by PRIMA-1. Cell Physiol Biochem 2015;35:529-540.

86 Fazio A, Briglia M, Faggio C, Alzoubi K, Lang F: Oxaliplatin Induced Suicidal Death of Human Erythrocytes. Cell Physiol Biochem 2015;37:2393-2404.

87 Fazio A, Briglia M, Faggio C, Alzoubi K, Lang F: Stimulation of Suicidal Erythrocyte Death by Garcinol. Cell Physiol Biochem 2015;37:805-815.

88 Gao C, Ji S, Dong W, Qi Y, Song W, Cui D, Shi J: Indolic Uremic Solutes Enhance Procoagulant Activity of Red Blood Cells through Phosphatidylserine Exposure and Microparticle Release. Toxins (Basel) 2015;7:43904403.

89 Hoque M, Nanduri R, Gupta J, Mahajan S, Gupta P, Saleemuddin M: Oleic acid complex of bovine alphalactalbumin induces eryptosis in human and other erythrocytes by a $\mathrm{Ca}(2+)$-independent mechanism. Biochim Biophys Acta 2015;1850:1729-1739.

90 Lang E, Jilani K, Bissinger R, Rexhepaj R, Zelenak C, Lupescu A, Lang F, Qadri SM: Vitamin D-Rich Diet in Mice Modulates Erythrocyte Survival. Kidney Blood Press Res 2015;40:403-412.

91 Lang E, Zelenak C, Eberhard M, Bissinger R, Rotte A, Ghashghaeinia M, Lupescu A, Lang F, Qadri SM: Impact of Cyclin-Dependent Kinase CDK4 Inhibition on Eryptosis. Cell Physiol Biochem 2015;37:1178-1186.

92 Malik A, Bissinger R, Liu G, Liu G, Lang F: Enhanced eryptosis following gramicidin exposure. Toxins (Basel) 2015;7:1396-1410.

93 Officioso A, Alzoubi K, Manna C, Lang F: Clofazimine Induced Suicidal Death of Human Erythrocytes. Cell Physiol Biochem 2015;37:331-341.

94 Officioso A, Manna C, Alzoubi K, Lang F: Triggering of Erythrocyte Death by Triparanol. Toxins (Basel) 2015;7:3359-3371.

95 Pagano M, Faggio C: The use of erythrocyte fragility to assess xenobiotic cytotoxicity. Cell Biochem Funct 2015;33:351-355.

96 Peter T, Bissinger R, Enkel S, Alzoubi K, Oswald G, Lang F: Programmed erythrocyte death following in vitro Treosulfan treatment. Cell Physiol Biochem 2015;35:1372-1380.

97 Peter T, Bissinger R, Lang F: Erythrocyte Shrinkage and Cell Membrane Scrambling after Exposure to the Ionophore Nonactin. Basic Clin Pharmacol Toxicol 2015;10.1111/bcpt.12455

98 Ran Q Xiang Y, Liu Y, Xiang L, Li F, Deng X, Xiao Y, Chen L, Chen L, Li Z: Eryptosis Indices as a Novel Predictive Parameter for Biocompatibility of Fe304 Magnetic Nanoparticles on Erythrocytes. Sci Rep 2015;5:16209.

99 Stockinger K, Bissinger R, Bouguerra G, Abbes S, Lang F: Enhanced Eryptosis Following Exposure to Carnosic Acid. Cell Physiol Biochem 2015;37:1779-1791.

100 Sun Y, Liu G, Li X, Shi Y, Guan G: L-Carnitine inhibits eryptosis induced by uremic serum and the related mechanisms. Ren Fail 2015;37:1050-1056.

101 Tesoriere L, Attanzio A, Allegra M, Livrea MA: Dietary indicaxanthin from cactus pear (Opuntia ficus-indica L. Mill) fruit prevents eryptosis induced by oxysterols in a hypercholesterolaemia-relevant proportion and adhesion of human erythrocytes to endothelial cell layers. Br J Nutr 2015;114:368-375.

102 Velasquez FC, Mate S, Bakas L, Herlax V: Induction of eryptosis by low concentrations of E. coli alphahemolysin. Biochim Biophys Acta 2015;1848:2779-2788.

103 Viskupicova J, Blaskovic D, Galiniak S, Soszynski M, Bartosz G, Horakova L, Sadowska-Bartosz I: Effect of high glucose concentrations on human erythrocytes in vitro. Redox Biol 2015;5:381-387.

104 Waibel S, Bissinger R, Bouguerra G, Abbes S, Lang F: Saquinavir Induced Suicidal Death of Human Erythrocytes. Cell Physiol Biochem 2015;37:1973-1982. 


\section{Cellular Physiology Cell Physiol Biochem 2016;38:379-392 \begin{tabular}{ll|l} 
DOI: 10.1159/000438638 & $\begin{array}{l}\text { O 2016 The Author(s). Published by S. Karger AG, Basel } \\
\text { www.karger.com/cpb }\end{array}$
\end{tabular} \\ Signoretto et al.: Nocodazole-Induced Eryptosis}

105 Zierle J, Bissinger R, Egler J, Lang F: Lapatinib Induced Suicidal Death of Human Erythrocytes. Cell Physiol Biochem 2015;37:2275-2287.

106 Calabro S, Alzoubi K, Bissinger R, Jilani K, Faggio C, Lang F: Enhanced eryptosis following juglone exposure. Basic Clin Pharmacol Toxicol 2015;116:460-467.

107 Gaffet P, Bettache N, Bienvenue A: Phosphatidylserine exposure on the platelet plasma membrane during A23187-induced activation is independent of cytoskeleton reorganization. Eur J Cell Biol 1995;67:336-345.

108 Lockshin RA, Zakeri Z: Apoptosis, autophagy, and more. Int J Biochem Cell Biol 2004;36:2405-2419.

109 Lockshin RA, Zakeri Z: Caspase-independent cell death? Oncogene 2004;23:2766-2773.

110 Naito M, Hashimoto C, Masui S, Tsuruo T: Caspase-independent necrotic cell death induced by a radiosensitizer, 8-nitrocaffeine. Cancer Sci 2004;95:361-366.

111 Borst 0, Abed M, Alesutan I, Towhid ST, Qadri SM, Foller M, Gawaz M, Lang F: Dynamic adhesion of eryptotic erythrocytes to endothelial cells via CXCL16/SR-PSOX. Am J Physiol Cell Physiol 2012;302:C644-C651.

112 Andrews DA, Low PS: Role of red blood cells in thrombosis. Curr Opin Hematol 1999;6:76-82.

113 Chung SM, Bae ON, Lim KM, Noh JY, Lee MY, Jung YS, Chung JH: Lysophosphatidic acid induces thrombogenic activity through phosphatidylserine exposure and procoagulant microvesicle generation in human erythrocytes. Arterioscler Thromb Vasc Biol 2007;27:414-421.

114 Zwaal RF, Comfurius P, Bevers EM: Surface exposure of phosphatidylserine in pathological cells. Cell Mol Life Sci 2005;62:971-988.

115 Closse C, Dachary-Prigent J, Boisseau MR: Phosphatidylserine-related adhesion of human erythrocytes to vascular endothelium. Br J Haematol 1999;107:300-302.

116 Gallagher PG, Chang SH, Rettig MP, Neely JE, Hillery CA, Smith BD, Low PS: Altered erythrocyte endothelial adherence and membrane phospholipid asymmetry in hereditary hydrocytosis. Blood 2003;101:46254627.

117 Pandolfi A, Di Pietro N, Sirolli V, Giardinelli A, Di Silvestre S, Amoroso L, Di Tomo P, Capani F, Consoli A, Bonomini M: Mechanisms of uremic erythrocyte-induced adhesion of human monocytes to cultured endothelial cells. J Cell Physiol 2007;213:699-709.

118 Wood BL, Gibson DF, Tait JF: Increased erythrocyte phosphatidylserine exposure in sickle cell disease: flowcytometric measurement and clinical associations. Blood 1996;88:1873-1880. 